\title{
Effect of Time of The First Irrigation and Seeding Rates on Maize Yield and Yield Components
}

\author{
M.B.A. El-koomy, H. A. Darwish and M.A.A. Mostafa \\ Maize Research Department, Field Crops Research Institute, \\ Agricultural Research Center,Cairo, Egypt.
}

\begin{abstract}
7 HIS FIELD experiment was carried out through the successive growth season's summer 2014 and 2015 at Sids Agricultural Research Station to study the effect of the first irrigation $(17,21$ and 25 days after planting) and different rates of maize grains $(26250,39375,52500$ and 78750 grains per *faddan on maize yield productivity and component for Yellow single-cross 176 . The studies treatments were disturbed among the experimental plots in split plot design with four replicates. The obtained results cleared that, all studied characters of grain yield was highly significant for the time of first water irrigation, while the number of plants per fad was not significant. The first irrigation after 17 days from sowing gave the highest value of grain yield at both tested years (31.8 and 28.6 \# ardab/fad), while the irrigation at 21 days had moderate values of grain yield (27.7 and 28.0 ardab/fad) at 2014 and 2015, respectively. Also, the first seeding rates (one kernel per hill) had the lowest number of plants per fad at both seasons (21219 and 21171 plants/fad), while the second treatment (one and two kernels per hill, alternately, without thinning) gave the highest number of plants per fad at both years (26218 and 26208 plants). On the other hand, the first irrigation after 17 days from planting had the significant highest values of grain yield per plant at both seasons (177.9 and $171.8 \mathrm{gm}$ ). As well as, the first irrigation at 17 days had the significant highest values of ear diameter at $2014(4.62 \mathrm{~cm})$ compared to $4.50 \mathrm{~cm}$ when the first irrigation is running at 25 days. The first irrigation after 25 days from planting had the lowest number of days to mid-silking at 2014 season (57 days), while irrigation after 21 days had 58.7 days. The shortest plants were observed when the first irrigation running at 25 days $(231.9 \mathrm{~cm})$. Results showed that application of irrigation water after 17 days from planting, number 2 grains per hill and 52500 grains per fad had a positive effect on yield and yield component in both seasons. Significant and positive correlation coefficients were observed for grain yield with each of the number of plants and ears per fad at both years $\left(0.53^{* *}\right.$ and $0.45^{* *}$, respectively). Seeding rates and grain yield with each of the number of plants and ears per fad $(0.35 * *, 0.49 * * ; 0.43 * *, 0.54 * *$, respectively), significant and negative correlation values for grain yield per plant and each of first irrigation time and the number of plants at both seasons $\left(-0.35^{* *},-0.70^{* *},-0.34 *\right.$ and $-0.83^{* *}$, respectively). Significant negative correlation coefficients was observed for number of days to midsilking with the first irrigation at 2014 season $(-0.34 *)$ high significant correlation for plant height, at 2014 season, with time of first irrigation ($\left.0.52^{* *}\right)$, grain yield $\left(0.36^{* *}\right)$, number of plants per fad $\left(0.41^{* *}\right)$, and number of ears per fad $\left(0.46^{* *}\right)$.
\end{abstract}

Keywords: First irrigation time, Seeding rates, Maize grain yield.

$*$ faddan $=4200 \mathrm{~m}^{2} \quad$ \# ardab $=140 \mathrm{~kg}$ grain at $15.5 \%$ moisture 
The main goal of the Egyptian agricultural plan is increasing food production in order to reduce the food gap especially for main crops such as maize. The aims of food security strategy are to maximize the productivity per unit area and minimize production costs. Irrigation is one of the most important factors affecting maize growth, yield and its related components. The essential feature in plant water relations is the internal water balance, water stress, or degree of turgidity in plants, because the control of these physiological processes determines the quantity and quality of growth and yield. Water requirements and plant density play an important role in affecting maize yield. The frequent irrigation of every other furrow at 6-day intervals to sugar beet produced similar root yield to that of every-furrow irrigation at 10-days interval and saved an average of $23 \%$ of irrigation water and improved WUE by $43 \%$ (Sepaskhan \& Kamgar-Haghighi, 1997). Hussein et al. (2000) indicated that the maximum maize grain yield and the highest crop return were obtained from using $3360 \mathrm{~m}^{3}$ irrigation water and 24000 plants per fad. Ibrahim \& Kandil (2007) found that the highest values of plant height, ear length and grain yield of maize were obtained under irrigation intervals of 10 days followed by 14 and 18 days. Atta Eachah (1996) indicated that grain yield was significantly increased with shortening irrigation interval. Al-Henish (1999) reported that decreasing the irrigation intervals to 10 days significantly increased plant height and grain yield. El-Zubeir \& Mohamed (2011) recommended that 10 days irrigation interval gave the highest values of plant height, 100-seed weight and grain yield compared to 15 and 20 days irrigation intervals. Abdel-Halim (2013) stated that the highest grain yield of maize was associated with irrigation every 7 days, whereas the lowest grain yield was linked to irrigation every 14 days.

Plant density might be a successful strategy for increasing grain yield if the hybrids grown are not tolerant of greater competition. Contrasting responses of different germplasm sources to plant density have been documented (Troyer \& Rosenbrook, 1983; Cox, 1996; Sarlangue et al., 2007; Brekke et al., 2011 and Berzsenyi \& Tokatlidis, 2012). Yet there is a scarcity of hybrid by plant density interaction data for current commercial maize hybrids, nonetheless, it is clear that modern hybrids exhibit greater yields relative to older hybrids when interplant competition is increased (Tollenaar \& Wu, 1999; Duvick et al., 2004 and Hammer et al., 2009), and the optimum densities can vary between hybrids (Sarlangue et al., 2007). El-Gezawy (1996) and Shams El-Din \& El-Habbak (1996) indicated that grain yield of maize significantly increased by increasing plant density up to 24000 plants per fad. Badr \& Othman (2006) mentioned that increasing plant density from 20000 to 30000 plants per fad significantly increased plant height, ear height and grain yield. Hassan et al. (2008) indicated that plant density of 25 and 30 thousands plants per fad was associated with the highest grain yield. Also, Hassan et al. (2009) reported that plant densities had significant effect on maize grain yield. Valadabadi \& Farahani (2010) reported that leaf area was influenced by plant population.

Egypt. J. Agron. Vol. 38, No. 2 (2016) 


\section{Materials and Methods}

Two similar trials were conducted in 2014 and 2015 to investigate the contributions of the $1^{\text {st }}$ irrigation time (17, 21 and 25 days after planting) and seeding rates $(26250,39375,52500$ and 78750 seeds per fad) on growth and grain yield of yellow maize. The trials were located at Sids Agricultural Research Station Farm. Yellow single-cross 176 was used at this trial.

Seeding rate treatments were 26250 seeds per fad (one kernel per hill), 39375 seeds per fad (one and two kernels per hill, alternately, without thinning), 52500 seeds per fad (two kernels per hill thinned to one plant per hill) and 78750 seeds per fad (three kernels per hill, thinned to one plant per hill). Plot size was four rows, $80 \mathrm{~cm}$ width, $6 \mathrm{~m}$ long and $20 \mathrm{~cm}$ between hills. One blank row was left between plots. A split-plot design arrangement with four replications was used. The main plot (time of the first irrigation) consisted of twenty rows for each treatment of the irrigation, while the sub-plot was contained of seeding rates.All cultural practices were applied as recommended at the proper time. Data were collected for ears weight per plot $(\mathrm{kg})$, shelled, adjusted to $15.5 \%$ grain moisture and converted to grain yield (ardab/fad). Also, data were collected for some yield components and agronomic traits.Yield and other traits data were analyzed separately for each year using Proc ANOVA in SAS software (SAS released 2008). Time of the first irrigation and seeding rates were included as fixed effects while replications were included as random effects.

\section{Results and Discussions}

\section{Grain yield and number of plants and ears}

Significant and highly significant differences were observed for time of first irrigation on grain yield at both tested years, while number of plants and ears per fad were not affected by this factor (Table 1). Also, highly significant differences were detected for seeding rates on grain yield and number of plants and ears per fad at both seasons. Only the interaction of time of first irrigation with seeding rates was highly significant for grain yield at 2014 season.

The first irrigation after 17 days from sowing gave the highest value of grain yield at both tested years ( 31.8 and $28.6 \mathrm{ardab} / \mathrm{fad})$, while the irrigation at 21 days had moderate values of grain yield (27.7 and $28.0 \mathrm{ardab} / \mathrm{fad})$ at 2014 and 2015 , respectively (Table 1). The lowest significant values of grain yield were obtained when the first irrigation was added at 25 days after sowing (24.8 and $26.9 \mathrm{ardab} / \mathrm{fad}$ ) at both tested years. These results showed that the earlier first irrigation gave high values of grain yield, therefore, must be run this irrigation at 17 days after sowing in Sids region. These results are in harmony with those reported by Sani et al. (2008). 
TABLE 1. Time of first irrigation and seeding rates influences on grain yield, number of plants and ears per faddan during 2014 and 2015.

\begin{tabular}{|c|c|c|c|c|c|c|c|}
\hline \multirow{2}{*}{\multicolumn{2}{|c|}{ Treatment }} & \multicolumn{2}{|c|}{$\begin{array}{c}\text { Grain yield } \\
\text { ardab/fad }\end{array}$} & \multicolumn{2}{|c|}{ No. of plants/fad } & \multicolumn{2}{|c|}{ No. of ears /fad } \\
\hline & & 2014 & 2015 & 2014 & 2015 & 2014 & 2015 \\
\hline \multirow{3}{*}{$\begin{array}{l}\text { Time of } \\
\text { irrigation }\end{array}$} & 17 & $31.8 \mathrm{a}$ & $28.6 \mathrm{a}$ & 25019 & 23304 & 24187 & 23297 \\
\hline & 21 & $27.7 \mathrm{~b}$ & $28.0 \mathrm{ab}$ & 24320 & 24750 & 23367 & 23734 \\
\hline & 25 & $24.8 \mathrm{c}$ & $26.9 \mathrm{~b}$ & 23156 & 23984 & 22219 & 22703 \\
\hline \multirow{4}{*}{ Seeding rate } & 1 & $25.7 \mathrm{~b}$ & $25.2 \mathrm{c}$ & $21219 \mathrm{c}$ & $21171 \mathrm{c}$ & $20963 \mathrm{~b}$ & $20198 \mathrm{c}$ \\
\hline & 2 & $29.9 \mathrm{a}$ & $29.9 \mathrm{a}$ & $26218 \mathrm{a}$ & $26208 \mathrm{a}$ & $24500 \mathrm{a}$ & $24901 \mathrm{a}$ \\
\hline & 3 & $28.2 \mathrm{a}$ & $28.4 \mathrm{~b}$ & 24776 b & $24401 \mathrm{~b}$ & $23177 \mathrm{a}$ & $23078 \mathrm{~b}$ \\
\hline & 4 & $28.5 \mathrm{a}$ & $27.8 \mathrm{~b}$ & $24447 \mathrm{~b}$ & $24270 \mathrm{a}$ & $24390 \mathrm{a}$ & $24802 \mathrm{a}$ \\
\hline \multicolumn{2}{|c|}{ Source of variation } & & & & & & \\
\hline \multicolumn{2}{|c|}{ Time of irr. (Tr) } & $* *$ & $*$ & ns & ns & ns & ns \\
\hline \multirow{2}{*}{\multicolumn{2}{|c|}{ Sedding rate $(\mathrm{Sr})$}} & $* *$ & $* *$ & $* *$ & $* *$ & $* *$ & $* *$ \\
\hline $\operatorname{Tr} \times \mathrm{Sr}$ & & $* *$ & ns & ns & $\mathrm{ns}$ & ns & ns \\
\hline
\end{tabular}

Regarding to seeding rates, the sowing of one and two kernels per hill, alternately, without thinning had the highest significantly grain yield (29.9 ardab/fad) at both years (Table 1), while the sowing with one kernel per hill gave the significantly lowest grain yield at both years (25.7 and $25.2 \mathrm{ardab} / \mathrm{fad})$. The other two seeding rates (two and three kernels per hill, thinned to one plant/hill) didn't significantly different in grain yield and produced significantly lowest values than one and two kernels per hill treatment at 2015 season. The decrease in grain yield is mainly due to decrease the number of plants at fad. These results are agreed with results obtained by El-Douby et al. (2001). The interaction of first irrigation time with seeding rate was significant only for grain yield at 2014 season.

Number of plants per fad didn't affected by the first irrigation time (Table 1), while highly significant differences were observed of seeding rates for this trait. The first seeding rates (one kernel per hill) had the lowest number of plants per fad at both seasons (21219 and 21171 plants/fad), while the second treatment (one and two kernels per hill, alternately, without thinning) gave the highest number of plants per fad at both years (26218 and 26208 plants). The third treatment (two kernels per hill, thinned to one plant) and fourth treatment (three kernels per hill, thinned to one plant) gave moderate number of plants per fad at both seasons (24776, 24401, 24447 and 24270 plants per fad, respectively).

The results showed that the highest grain yield was obtained from the second seeding rates, where it had the highest number of plants per fad for the used hybrid (SC.176) at Sids region. Abd El-Zaher \& Hassan (2013) reported that grain yield was significantly affected by plant density, where the highest grain yield achieved was associated with 24000 plants per fad as compared with 20000 and 30000 plants per fad.

Egypt. J. Agron. Vol. 38, No. 2 (2016) 
Number of ears per fad had the same trend of number of plants at both years (Table 1). The treatment of one and two kernels per hill without thinning had significantly the highest number of ears at both years (24500 and 24901 ears/fad) (Table 1), while the one kernel per hill treatment had the lowest significantly number of ears (20963 and 20198 ears/fad). The fourth seeding rates treatment (three kernels/hill, thinned to one plant) at both years and the third treatment (two kernels/hill, thinned to one plant) did not significantly different than one and two kernels per hill at 2014 season (Table 1).

Highly significant correlation coefficients were observed for grain yield with each of number of plants and ears per fad at both years $\left(0.53^{* *}\right.$ and $0.45^{* *}$, respectively). Seeding rates and grain yield with each of number of plants and ears per fad $\left(0.35^{* *}, 0.49^{* *} ; 0.43^{* *}, 0.54 * *\right) ; 053^{* *}, 0.45^{* *}$, respectively (Table 4).

\section{Grain yield per plant}

Significant differences were observed among time of first irrigation treatments for grain yield per plant at both seasons (Table 2). Also, highly significant differences were detected among seeding rates for grain yield per plant at both years. The interaction of first irrigation time with seeding rates was highly significant for grain yield per plant at 2014 season only (Table 2).

TABLE 2. Time of first irrigation and seeding rates influences on grain yield per plant, ear length and ear diameter during 2014 and 2015.

\begin{tabular}{|c|c|c|c|c|c|c|c|}
\hline \multirow[t]{2}{*}{ Treatment } & & \multicolumn{2}{|c|}{$\begin{array}{l}\text { Grain yield / } \\
\text { plant }(\mathrm{g})\end{array}$} & \multicolumn{2}{|c|}{$\begin{array}{l}\text { Ear length } \\
\text { (cm) }\end{array}$} & \multicolumn{2}{|c|}{$\begin{array}{c}\text { Ear diameter } \\
(\mathbf{c m})\end{array}$} \\
\hline & & 2014 & 2015 & 2014 & 2015 & 2014 & 2015 \\
\hline \multirow{3}{*}{$\begin{array}{l}\text { Time of } \\
\text { irrigation }\end{array}$} & 17 & $177.9 \mathrm{a}$ & $171.8 \mathrm{a}$ & $21.4 \mathrm{a}$ & 20.1 & $4.62 \mathrm{a}$ & 4.42 \\
\hline & 21 & $159.4 \mathrm{~b}$ & $158.4 \mathrm{~b}$ & $20.1 \mathrm{~b}$ & 19.7 & $4.58 \mathrm{ab}$ & 4.40 \\
\hline & 25 & $149.9 \mathrm{~b}$ & $157.0 \mathrm{~b}$ & $20.2 \mathrm{~b}$ & 19.7 & $4.50 \mathrm{~b}$ & 4.36 \\
\hline \multicolumn{8}{|c|}{ Seeding rate } \\
\hline & 1 & $169.6 \mathrm{a}$ & $166.6 \mathrm{a}$ & $21.2 \mathrm{a}$ & $20.4 \mathrm{a}$ & 4.61 & 4.47 \\
\hline & 2 & $159.7 \mathrm{~b}$ & $159.7 \mathrm{~b}$ & $19.8 \mathrm{~b}$ & $19.3 \mathrm{c}$ & 4.55 & 4.32 \\
\hline & 3 & $159.3 \mathrm{~b}$ & $169.9 \mathrm{a}$ & $21.0 \mathrm{a}$ & $20.1 \mathrm{ab}$ & 4.57 & 4.38 \\
\hline & 4 & $163.2 \mathrm{a}$ & $154.0 \mathrm{bc}$ & $20.3 \mathrm{~b}$ & $19.6 \mathrm{bc}$ & 4.53 & 4.42 \\
\hline \multicolumn{8}{|c|}{ Source of variation } \\
\hline Time of irr & & $*$ & * & * & ns & * & Ns \\
\hline Sedding ra & & $* *$ & $* *$ & $* *$ & * & Ns & Ns \\
\hline $\operatorname{Tr} \times \mathrm{Sr}$ & & $* *$ & ns & ns & ns & Ns & Ns \\
\hline
\end{tabular}

The first irrigation after 17 days from sowing had significant highest values of grain yield per plant at both seasons (177.9 and $171.8 \mathrm{gm}$ ). The other two irrigation treatments didn't differed significantly and they had the lowest values of grain yield per plant $(159.4,158.4,149.9$ and $157.0 \mathrm{gm}$, respectively). The first seeding rates, which had the lowest number of plants per fad, gave the highest values of grain yield per plant at both years (169.6 and 169.9 gm). The second seeding rates, which had the highest number of plants, gave low values of 
grain yield per plant (159.7 gm) at both seasons. The decreased in values of grain yield per plant as plant density increased is mainly due to the increase in competition among plants for light, nutrients and other environmental factors, which are required for growth. These results are in a accordance with those obtained by El-Gezawy (1996) who reported that yield components of maize, i.e., kernels weight, ear length and yield per plant significantly decreased as a result of increasing population density.

The results on Table 4 showed significant and negative correlation coefficients values for grain yield per plant and each of first irrigation time and number of plants at both seasons $\left(-0.35^{* *},-0.70^{* *},-0.34 *\right.$ and $-0.83 * *$, respectively). Also, the same relation was detected for grainy yield per plant with number of ears per plant at $2014(-0.53 * *)$, while significant positive relation was found with grain yield per fad at 2014 season $\left(0.41^{* *}\right)$.

\section{Ear length}

Ear length at 2014 seasons was significantly affected by the time of first irrigation, while significant differences were detected among seeding rates at both years (Table 2). When the first irrigation was done after 17 days from sowing, it gave the significant highest values of ear length at 2014 season $(21.4 \mathrm{~cm})$ compared with the other irrigation treatments $(20.1$ and $20.2 \mathrm{~cm})$. The first seeding rates, which had the lowest plant density, gave the significant highest values of ear length at both years $(21.2$ and $20.4 \mathrm{~cm})$. The second seeding rates, which had the highest plant density, gave the significant lowest values of ear length at both seasons $(19.8$ and $19.3 \mathrm{~cm})$. These results are in agreement with that obtained by El-Gezawy (1996) and Abd El-Zaher \& Hassan (2013). Significant negative correlation were found for ear length with number of days to mid-silking and plant height at 2014 season $(-0.49 * *$ and $-0.37 * *$, Table 4). Also, significant negative correlation were found for ear length with number of plants and ears at 2015 season $\left(-0.38^{* *}\right)$ as showed on Table 4 .

\section{Ear diameter}

Significant differences were observed among first irrigation time for ear diameter at 2014 season only (Table 2). While the seeding rates didn't affect ear diameter in both seasons under this study. The first irrigation at 17 days had the significant highest values of ear diameter at $2014(4.62 \mathrm{~cm})$ compared by 4.50 $\mathrm{cm}$ when the first irrigation is running at 25 days. Significant relation value was observed for ear diameter with plant height at 2014 season $\left(0.34^{*}\right.$, Table 4). Also, highly significant correlation value was found between ear diameter and ear length at 2015 season $(0.47 * *)$ as showed on Table 4.

\section{Kernels weight}

No significant differences were detected for time of first irrigation factor on kernels weight at both seasons (Table 3). Also, seeding rates and its interaction with time of first irrigation were not significantly affected at 2014 season. The third and fourth seeding rate treatments had significant high values of 100-kernels weight at 2015 season (34.6 and 34.7 gm, respectively) compared with the first and second

Egypt. J. Agron. Vol. 38, No. 2 (2016) 
seeding rate treatments, as showed at Table 2. Significant correlation was observed for kernels weight with seeding rates at 2015 season only $\left(0.35^{*}\right)$ (Table 4$)$.

TABLE 3. Time of first irrigation and seeding rates influences on kernels weight, number of days to mid-silking and plant height during 2013 and 2014.

\begin{tabular}{|c|c|c|c|c|c|c|c|}
\hline \multirow{2}{*}{\multicolumn{2}{|c|}{ Treatment }} & \multicolumn{2}{|c|}{$\begin{array}{c}\text { 100-Kernel } \\
\text { weight }\end{array}$} & \multicolumn{2}{|c|}{$\begin{array}{l}\text { Days to mid- } \\
\text { silking }\end{array}$} & \multicolumn{2}{|c|}{ Plant height } \\
\hline & & 2014 & 2015 & 2014 & 2015 & 2014 & 2015 \\
\hline \multicolumn{2}{|c|}{ Time of irrigation } & \multicolumn{2}{|c|}{ Gram } & \multicolumn{2}{|c|}{ Number } & \multicolumn{2}{|c|}{ centimeter } \\
\hline & 17 & 31.6 & 33.7 & $60.3 \mathrm{a}$ & 60.0 & $246.3 \mathrm{a}$ & 246.2 \\
\hline & 21 & 31.6 & 34.4 & $58.7 \mathrm{~b}$ & 60.0 & $246.9 \mathrm{a}$ & 247.2 \\
\hline & 25 & 30.6 & 34.3 & $57.0 \mathrm{c}$ & 59.0 & $231.9 \mathrm{~b}$ & 244.4 \\
\hline \multicolumn{8}{|l|}{ Seeding rate } \\
\hline & 1 & 31.3 & $33.7 \mathrm{~b}$ & 59.0 & 60.0 & 237.9 & 245.4 \\
\hline & 2 & 31.4 & $33.7 \mathrm{~b}$ & 58.1 & 59.9 & 240.0 & 249.2 \\
\hline & 3 & 31.3 & $34.6 \mathrm{a}$ & 58.4 & 59.4 & 245.0 & 244.2 \\
\hline & 4 & 30.8 & $34.7 \mathrm{a}$ & 59.1 & 59.3 & 243.7 & 245.0 \\
\hline \multicolumn{8}{|c|}{ Source of variation } \\
\hline Time of irr. (Tr) & & ns & ns & $* *$ & Ns & $*$ & ns \\
\hline Sedding rate $(\mathrm{Sr}$ & & ns & $*$ & ns & Ns & Ns & ns \\
\hline $\operatorname{Tr} \times \mathrm{Sr}$ & & $\mathrm{ns}$ & $*$ & ns & Ns & Ns & ns \\
\hline
\end{tabular}

TABLE 4. Correlation means for time of irrigation and seeding rates with grain yield and other traits of maize SC.176 during 2014 and 2015.

\begin{tabular}{|c|c|c|c|c|c|c|c|c|c|c|c|}
\hline & $\mathbf{T r}$ & $\mathrm{Sr}$ & Gy & Pln & Ern & Gyp & El & Ed & Kwt & Silk & Plht \\
\hline $\operatorname{Tr}$ & -- & 0.0 & $-0.65 * *$ & $-0.29 *$ & $-0.30 *$ & $-0.35 *$ & $0.40 * *$ & $-0.37 * *$ & 0.16 & $-0.34 *$ & $-0.52 * *$ \\
\hline $\mathrm{Sr}$ & 0.0 & -- & 0.17 & $0.35 * *$ & $0.49 * *$ & 0.14 & $-0.44 * *$ & -0.19 & $0.35^{*}$ & 0.03 & 0.22 \\
\hline Gy & -0.27 & $0.67 * *$ & -- & $0.53 * *$ & $0.45^{* * *}$ & $0.41 * *$ & -0.20 & 0.23 & -0.01 & $* 0.04$ & $0.36 * *$ \\
\hline Plno & 0.11 & $0.43 * *$ & $0.53 * *$ & -- & $0.80 * *$ & $-0.70 * *$ & 0.16 & 0.01 & 0.02 & 0.03 & $0.41 * *$ \\
\hline Erno & -0.09 & $0.54 * *$ & $0.45 * *$ & $0.81 * *$ & -- & $-0.53 * *$ & 0.05 & 0.04 & 0.19 & -0.08 & $0.46^{* *}$ \\
\hline Gyp & $-0.34 *$ & -0.17 & 0.19 & $-0.83 * *$ & 0.05 & --- & -0.25 & 0.18 & 0.14 & -0.03 & 0.12 \\
\hline $\mathrm{El}$ & -0.12 & -0.18 & -0.32 & $-0.38 * *$ & $-0.38 * *$ & 0.20 & --- & 0.16 & -0.09 & $-0.49 * *$ & $-0.37 * *$ \\
\hline $\mathrm{Ed}$ & -0.14 & -0.05 & -0.01 & $-0.29 *$ & -0.06 & 0.26 & $0.47 * *$ & --- & -0.01 & -0.01 & $0.34 *$ \\
\hline Kwt & -0.22 & -0.10 & -0.01 & 0.02 & 0.19 & 0.15 & 0.18 & 0.21 & -- & -0.13 & 0.10 \\
\hline Silk & $-0.34 *$ & -0.23 & 0.08 & 0.25 & 0.05 & -0.03 & 0.03 & -0.04 & 0.09 & -- & $0.32 *$ \\
\hline Plht & -0.12 & -0.11 & 0.05 & 0.22 & 0.18 & 0.12 & -0.23 & -0.10 & 0.06 & 0.25 & --- \\
\hline
\end{tabular}




\section{Days to mid-silking}

The results showed that number of days to mid-silking was affected by time of first irrigation only at 2014 season (Table 3). The first irrigation after 25 days from sowing had the lowest number of days to mid-silking at 2014 season (57 days), while irrigation after 21 days had 58.7 days. At contrast, irrigation at 17 days after sowing had 60.3 days to reached of mid-silking. Seeding rates was not affected of days to mid-silking at both seasons (Table 3). Significant negative correlation coefficients was observed for number of days to mid-silking with the first irrigation at 2014 season $\left(-0.34^{*}\right)$ as showed at Table 4.

\section{Plant height}

Significant differences were observed for plant height due to time of first irrigation at 2014 season (Table 3). No differences were detected between first irrigation at 17 and 21 days after sowing. The shortest plants were observed when the first irrigation running at 25 days $(231.9 \mathrm{~cm})$. Plant height didn't affected by seeding rates at both seasons (Table 3). The results at Table 4 showed high significant correlation for plant height, at 2014 season, with time of first irrigation $\left(-0.52^{* *}\right)$, grain yield $\left(0.36^{* *}\right)$, number of plants per fad $\left(0.41^{* *}\right)$, and number of ears per fad $\left(0.46^{* *}\right)$.

\section{Reference}

Abdel-Halim, A. (2013) Impact of alternate furrow irrigation with different irrigation intervals on yield, water use efficiency, and economic return of corn. Chilean J. Agric. Res. 73 (2) Chillan Jun.

Abd El-zaher, Sh. R. and Hassan, M. M. M. (2013) Effect of irrigation intervals , preceding crop, and plant density on yield and yield components of maize. Egypt . J. of Appl. Sci. 28 (11), 559-574 .

Al-Henish, T.I. (1999) Effect of irrigation intervals herbicidal rates and application methods on maize and succeeding crops in relation to physiological and chemical traits . Ph. D. Thesis, Fac. Agric., Cairo Univ., Egypt.

Atta Eachah, S.A.A. (1996) Effect of irrigation intervals and plant densities on growth, yield and its components of some maize varieties .Proc. $7^{\text {th }}$ Conf Agron., $9^{\text {th }}-10^{\text {th }}$ Sept., pp. 59-70 .

Badr, M.M.A., and Othman, Sanaa A. (2006) Effect of plant density, organic manure,bio- and mineral nitrogen fertilizers on maize growth and yield and soil fertility, Annals Agric. Sci. Moshtohor, 44(1), 75-88.

Berzsenyi, Z. and Tokatlidis, I.S. (2012) Density dependence rather than maturity determines hybrid selection in dry land maize production. Agron. J. 104, 331-336.

Brekke, B., Edwards, J. and Knapp, A. (2011) Selection and adaptation to high plant density in the Iowa stiff stalk synthetic maize (Zea mays L.) population. CropSci. 51, 1965-1972.

Egypt. J. Agron. Vol. 38, No. 2 (2016) 
Cox, W.J. (1996) Whole-plant physiological and yield responses of maize to plant density. Agron. J. 88, 489-496.

Duvick, D.N., Smith, J.S.C. and Cooper, M. (2004) Long-term selection in a commercial hybrid maize breeding program. In: "Plant Breeding Reviews. Part 2. Long Term Selection: Crops, Animals and Bacteria" J. Janick (Ed.), pp. 109-151, 24, John Wiley \& Sons, New York..

EL-Douby, K.A., Ali, E.A., Toaima, S.E.A. and Abdel-Aziz, A.M. (2001) Effect of nitrogen fertilizater defoliation and plant density on maize grain yield. Egyption Journal of Agricultural Research,79(3), 965-982.

EL-Gezawy, N.Kh.B. (1996) The effect of nitrogen fertilizer and agrisp on the yield of some maize varieties (Zea mays L.). M.Sc . Thesis, Fac. Agric. Moshtohor, Zagazig Univ. Egypt.

EL-Zubeir, A.O. and Mohamed, A.E. (2011) Irrigation scheduling for maize (Zea mays.L) under desert area conditions-north of sudan. Agric.Biol. J.N.Am. 2(4), 645651.

Hammer, G.L., Dong, Z., McLean, G., Doherty, A., Messina, C. and Schussler, J. et al. (2009) Can changes in canopy and/or root system architecture explain historical maize yield trends in the U.S. corn belt. Crop Sci. 49, 299-312.

Hassan, M.M.M., El-Ghonemy, M.A.M. and Eachy, R.S.H. (2008) Response of some maize single cross hybrids to plant density under different Egyptian environmental conditions. Menufiya J. Agric. Res. 33(2), 427-443.

Hassan, M.M.M., El-Mekser, Hoda Kh. A. and El-Galfy, A.M.K. (2009) Response of some maize inbred lines to nitrogen fertilizer rates and plant population densities. Annals of Agric. Sci., Moshtohor, 47(3), 175-184.

Hussein, Samira M.A., Haikel, M.A. and El-Melegy, A.M. (2000) Effect of water requirements and plant densities on yield and its attributes of corn (Zea mays L.) under drip irrigation system in newly reclaimed soil in north Sinai. J. Agric. Sci. Mansoura Univ. 25 (5), 2439-2448.

Ibrahim, S.A. and Kandil, Hala (2007) Growth, yield and chemical constituents of corn (Zea mays.L) as affected by nitrogen and phosphors fertilization under different irrigation intervals. Journal of Applied Sciences Research, 3(10), 1112- 1120.

Sani, B.M., Oluwasemire, K.O. and Mohammed, H.I. (2008) Effect of irrigation and plant density on growth, yield and water use efficiency of early maize in the Nigerian savanna. Journal of Agricultural and Biological Science, 3 (2) , 33-40.

Sarlangue, T., Andrade, F.H., Calvino, P.A. and Purcell, L.C. (2007) Why do maize hybrids respond differently to variations in plant density? Agron. J. 99, 984-991.

Sepaskhan, A. R. and Kamgar-Haghighi, A. A. (1997) water use and yields of sugar beet grown under ever other furrow irrigation with different irrigation intervals. Agricultural Water Management, 34, 71-79. 
Shams El -Din, G.M. and EL-Habbak , K.E. (1996) Use of nitrogen and potassium fertilization levels by maize grown under plant densities for grain yield. Ann Agric . Sci., Moshtohor, Zagazig Univ.34 (2), 513 - 528.

Tollenaar, M. and Wu, J. (1999) Yield improvement in temperate maize is attributable to greater stress tolerance. Crop Sci. 39, 1597-1604.

Troyer, A.F., and Rosenbrook, R.W. (1983) Utility of higher plant densities for corn performance testing. Crop Sci. 23, 863-867.

Valadabadi, S.A. and Farahani, H.A. (2010) Effects of planting density and pattern on physiological growth indices in maize (Zea mays L.) under nitrogenous fertilizer application. Agric. Ext. and Rural Dev. 2(3), 40 - 47.

(Received 6/4/2016; accepted 18/8/2016) 


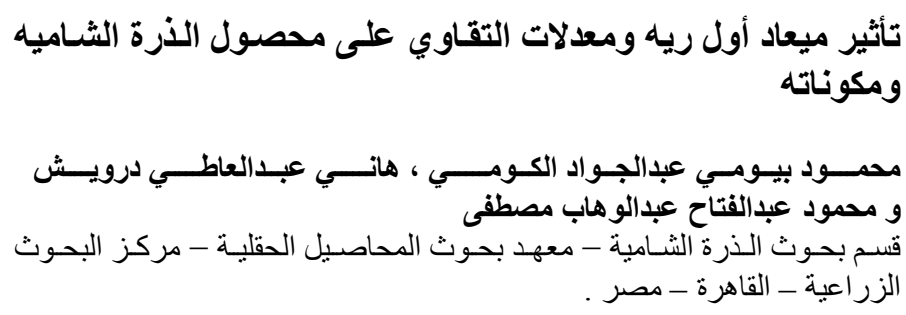

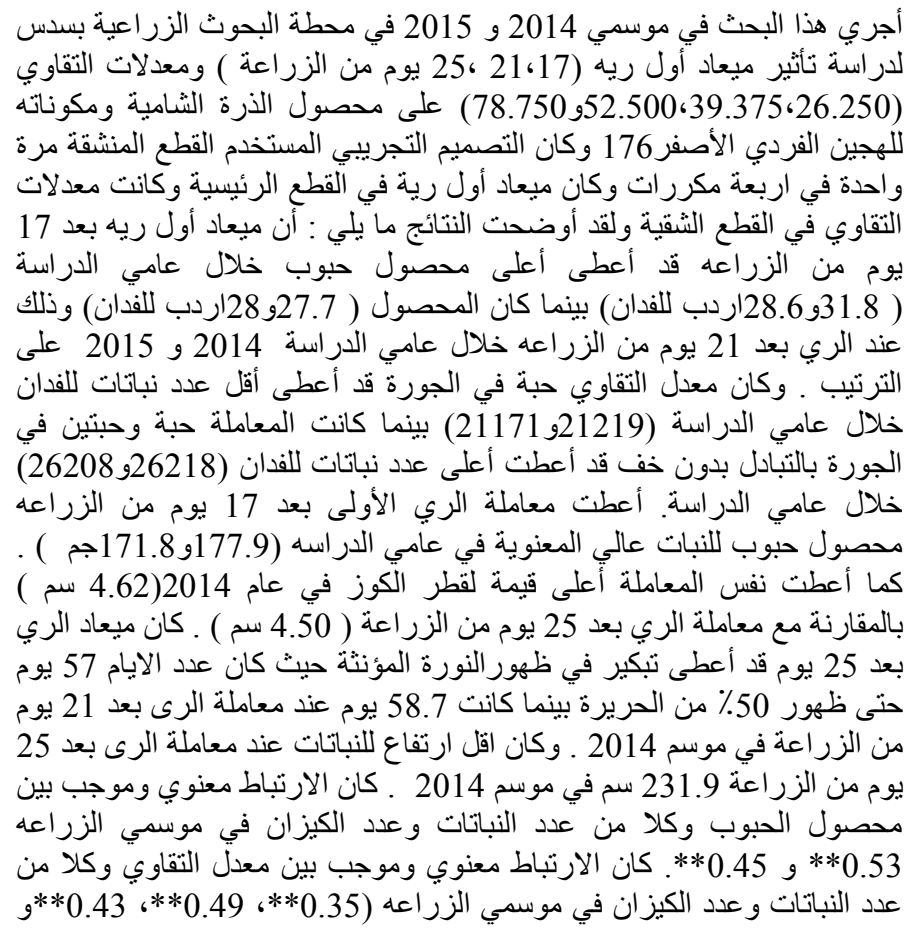

. $(* * 0.54$

كان الارتباط معنوي وسالب بين محصول النبات وكلا من ميعاد أول ريه

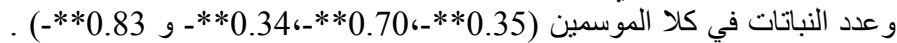

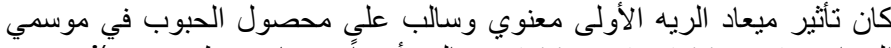

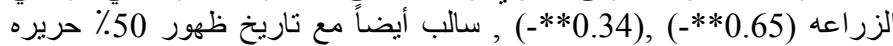

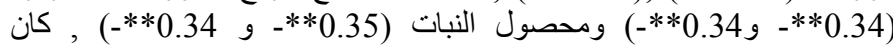

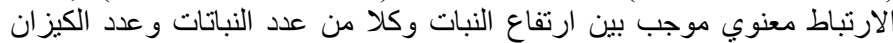

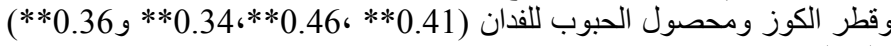
على الترتيب في موسم ومسول 2014 .

يتضح مما سبق ان الرى بعد 17 يوم من الزر اعة ومعد ومعل تقاوي حبة وحبتين

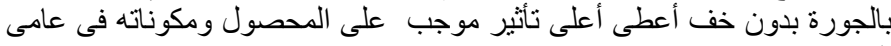
الدراسة 